\title{
Row Planting Under Inter and Mixed Cropping Systems as Sustainable Agricultural Practice in Central Highlands of Wolaita, Ethiopia
}

\author{
Nigatu Gebremedhin Enamo* \\ Department of Natural Resource Management, Wolkite University, Ethiopia
}

Submission: July 08, 2019; Published: August 01, 2019

*Corresponding author: Nigatu Gebremedhin Enamo, Department of Natural Resource Management, Wolkite University, Ethiopia

\begin{abstract}
Although Ethiopia has made tremendous effort in transforming the economy, the sector of agriculture has not shown significant change. In recent years, its contribution to the GDP was reported even less than the service sector. Yet the sector is characterized by long rooted backward agricultural practices where sluggish adoption of improved technologies are evident. This study examined farmer's practices of row planting under inter and mixed cropping systems in the central highlands of Wolaita Zone. A mixed research approach was applied to identify the major determinants affecting farmers adoption of the technology. Among the many kebeles in the highland, 3 kebeles were selected purposively considering farm size and settled population density. Hence, a total of 304 household heads practicing mixed and inter-cropping practices were systematically selected for the questionnaire survey. Binomial logistic regression was then applied to assess farmers' adoption of row planting under inter and mixed cropping systems. The model was explained between 8.6\% (Cox and Snell R square) and $14.4 \%$ (Nagelkerke R square) of the variance in adoption status and correctly classified $83.2 \%$ of cases. The findings revealed that extension contact (scoring an odds ratio of 7.27) and training (odds of 2.287) imposed a significant positive impact on the adoption of row planting under inter and mixed farming practices. Therefore, greater attention should be paid towards extension service and farmer's training to diffuse the practice among farmers in the highland.
\end{abstract}

Keywords: Row planting; Binomial regression; Adoption; Agroecology

Abbreviation: CSA: Central Statistical Agency; ETB: Ethiopian Birr; GDP: Gross Domestic Product; EMFED: Ethiopian Ministry of Finance and Economic Development; DEM: Digital Elevation Model; USGS: United States Geological Survey.

\section{Introduction}

\section{Background of the study}

Ethiopia achieved strong economic growth and expanded social services over the past decades. According to the data from EMFED, economic growth was averaged 10.5, recording more than doubled per capita GDP between 2010/11 ( $\$ 32$ billion) and 2016/17 (\$81 billion) [1].

Although the country has made tremendous effort in transforming the economy, the sector of agriculture has not shown significant change contributing only $36.3 \%$ to the GDP which is even less than the service sector (39.3\%). Moreover, rural poverty remained still a challenge where $25.6 \%$ of the population living below the national poverty line [1]. Small farm agriculture practiced by $57 \%$ of Ethiopian households challenged by land size, is yet sluggish and is at a subsistent level [1]. As cited in the Ethiopian National Human Development Report by UNDP [1], Bezu \& Holden [2] stated that landlessness is reported as a very critical problem nowadays where majority of households own averaged land size of 1.22 hectares and the majority of youths do not have their land despite their constitutional right. This problem is also witnessed in the central highlands of Wolaita. The kebeles in this highlands are the most densely populated administrative structure in Ethiopia where 746 persons reside in asingle kilometer square area of rural land [2]. Nigatu \& Tsetadir-gachew [3], revealed that average per capita landholding in theirdistrict was 0.25 with the chance of fragmentation through inheritance every 24 years. Their finding is in line with data obtainedfrom Wolaita zone.

Agricultural technologies whether indigenous or adopted are, therefore, essential in transforming the stagnant and severely endangered Ethiopian small farm agriculture. Appropriate application of cropping system and application of agricultural supplements can support agricultural productivity of farmers living under land scarcity [3,4]. According to the World Bank [5], adoption and proper utilization of yield increasing technologies supported 
revealed that farmers who applied chemical fertilizer earned greater income in ETB than non-adopters in southern Tigray. Moreover, Nigatu \& Tsetadirgachew [3], on their study found that farmers who attended training produced more organic compost than no- attendants. Well managed tillage practices are also reported to have a greater contribution in reducing soil erosion [7]. Moreover, as reported in FAO [8], Pretty et al., (2008), pointed out that yield can be increased by $79 \%$ if sustainable agricultural practices are adopted.

Among the major agronomic practices, row planting is among the new technologies presented to the farming practices of farmers by the Ethiopian government [9]. Farmers in Ethiopia or anywhere else in the world are expected by agricultural researchers to be knowledge intensive rather than being input intensive [10]. In this regard, various newly introduced technologies have been adopted at varying scale among farmers in Ethiopia [11]. For instance, in the 2013 cropping season, farmers applied $71 \%$, $66 \%, 60 \%, 52 \%, 46 \%$ \& $29 \%$ of potato, wheat, maize, teff, barley, and sorghum technology packages respectively in Ethiopia [11]. Although innovations are being mainstreamed into the farming community, adoption levels are still determined by a range of factors. According to Panell D.G et al. [12]; Nigatu \& Tsetadirgachew [3]; EGWU \& Emeka [13]; M. Z. et al. [14], socio-economic, individual \& institutional factors determine adoption of soil management technologies. Furthermore, resource endowment of farmers and income-generating capacity have been found to have a significant effect in determining the adoption of agricultural technologies in Ethiopia [14-18]. More recent studies are also assessing the impact of social networks on the adoption of new technologies [19].

Like many other agronomic practices, row planting is determined by a range of factors. Row planting is an agronomic prac- tice where crops are planted in a row of fixed-width allowing easy transportation and supply of water and nutrients [20]. As reported by many studies, farmers who adopted and practiced row planting technology produced greater production [21-23]. Although it is an old finding, Singh G et al. [21], reported the significant impact of row planting on yields of maize and soya bean.

Mainstreaming row planting as a sustainable agricultural practice in various agronomic practices commenced a few years ago by the Ethiopian government. Mixed cropping and intercropping are among the commonly practiced type of cropping systems in which row planting as a technique can be practiced. The farmers in Wolaita, particularly those in the highlands are well-known by intercropping and mixed cropping systems. The government has recently introduced row planting to the practices through its extension service. Hence, this study tries to examine the farmer's level of adoption of row planting under inter and mixed cropping agronomic systems as sustainable agricultural practices in the central highlands of Wolaita Zone, Ethiopia.

\section{Materials and Methods}

\section{The study area}

Wolaita zone is positioned within southwestern Ethiopia's enset culture systems. Astronomically the zone is located within $37^{\circ} 13^{\prime} 12 \mathrm{E}$ to $38^{\circ} 7^{\prime} 57^{\prime \prime} \mathrm{E}$ and $6^{\circ} 31^{\prime} 9^{\prime \prime} \mathrm{N}$ to $7^{\circ} 11^{\prime} 39^{\prime \prime} \mathrm{N}$ and dominantly inhabited by Wolaita speakers. The zone is bordered by Dawuro zone in the West, Sidama and Gofa zone in the East, Hadiya Zone in the North, and Gamo zone in the South. Its physiography is characterized by lowlands, highlands and rugged terrains. Altitude in the zone ranges from 621meters along the valleys of Omo river and extends to height of 2951meters in Damota chain mountains. The majority of the physiography of Wolaita is covered by highlands, within Woina Dega agroecology.

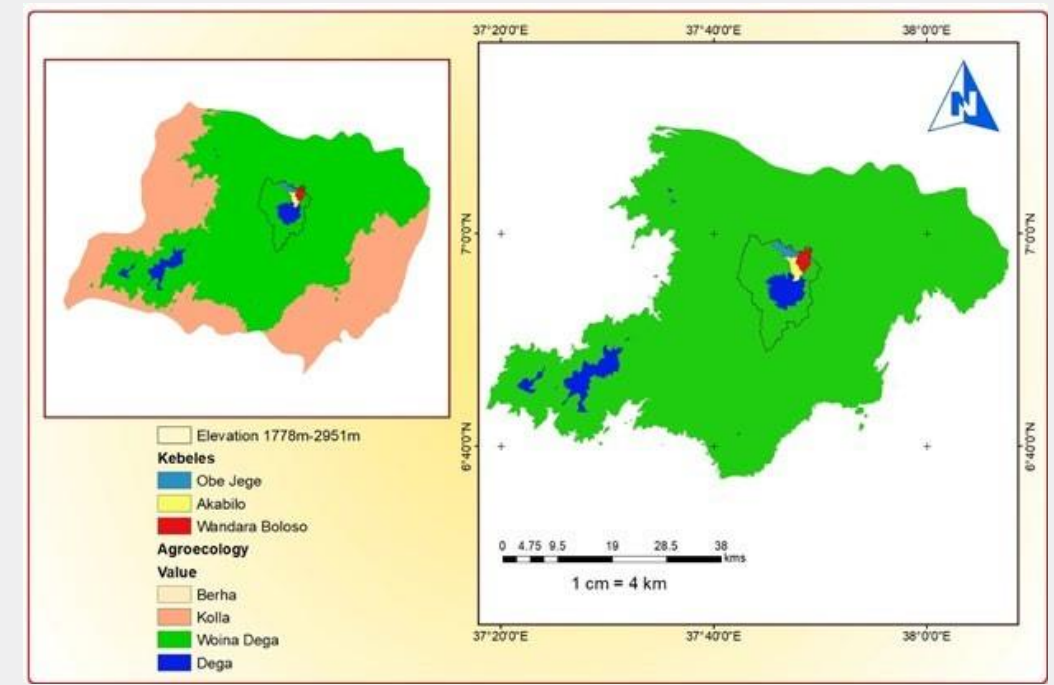

Figure 1: Agro-ecological zones of Wolaita Zone and sampled kebeles.

Source: DEM downloaded from USGS. 
The mean annual rainfall data experiences lowest in the lowlands $(803 \mathrm{~mm})$ at Abela Faracho. The highest mean annual rainfall of $1189 \mathrm{~mm}$ recorded at Soddo in the highlands. However, higher spatial variability is observed over the growing seasons. The major soil types found in the zone are Nitosols, haplic Yermosols, eutric Cambisols, orthic Andisols and calcaric Fluvisols [24]. Agriculture is the dominant economic activities where crop production involving root crops, cereals and perennials are the $d$ inant practices.

\section{Research approach and sampling}

This study applied mixed approach research with an ambition to answer both qualitative and quantitative aspects of the problem under investigation [25]. Although both quantitative and qualitative techniques have been applied in this study, the study bends towards a quantitative approach [26].

Sampling commonly depends on sampling error, level of precision, homogeneity of population and formulas used to determine the size of the study population $[25,26]$. However, most commonly size of the population, type, and objective of the study are the bas es for sample size determination[25-27].

A multi-stage sampling technique has been applied for this study. Purposive sampling was employed to sample out three kebeles having higher land scarcity among the many kebeles in the in the intermediate Dega and Woina Dega agroecology. All kebeles within elevation range of more than 1778 meters were identifiedbased on digital elevation model downloaded from USGS. Accordingly, fifteen kebeles were identified and ranked based on their settled population and average per capita land holdings. Finally, three kebeles namely Obe Jage, Akabilo and Wandara Bolosso were sampled based on their rank. After the careful identification of study kebeles, the list of households from selected kebeles were used to pick out samples based on systematicrandom sampling. Fortunately, all the three kebeles were from one district called Damot Gale district. Therefore, depending on the statistical data obtained from the CSA and Damot Gale district, about $10.18 \%$ of the total households i.e. 304 household heads were selected for this study.

\section{Data collection techniques}

Quantitative data, particularly survey data were collected using a questionnaire checklist. The validity of the questionnaire was tested through a pilot survey before the actual survey to reject confusing questions from the questionnaire. After the pilot survey, the main data collection was started on February 25 and finalized on April 3, 2018. During the survey, the data collectors were directed and supervised by the researcher. Due to the fact that enumerators were agricultural experts of the selected kebeles having close contact with selected samples, the questionnaire survey was finalized on its planned schedule.

\section{Data organization and analysis}

Both qualitative and quantitative data collected from the field were organized in a way suitable for data analysis. Questionnaire checklists collected were cleaned up, coded, organized and made ready for analysis on the SPSS version 19 package. Binomial logistic regression was applied to examine small farm holders' practice of row planting as sustainable agricultural practice under inter and mixed cropping systems in the land scarce central highlands of Wolaita.

\section{The binomial logistic regression}

The binomial logistic regression was then employed to investigate the effect of explanatory variables on the likelihood of adoption of row planting technology under inter and mixed cropping practices assustainable agricultural practices among farmers in the centralhighlands of Wolaita. The explanatory variables were ;

$$
\begin{aligned}
& \mathrm{X}_{1} \text { : Size of land } \\
& \mathrm{X}_{2} \text { : Farmers Training } \\
& \mathrm{X}_{3} \text { : Availability of TV, Radio } \\
& \mathrm{X}_{4} \text { : Educational status } \\
& \mathrm{X}_{5} \text { : Age } \\
& \mathrm{X}_{6}: \text { Sex } \\
& \mathrm{X}_{7}: \text { Frequency of extension contact }
\end{aligned}
$$

\section{Model Specification}

\section{The binomial logistic regression: "adoption of row planting"}

The objective of this research was to assess factors determining the adoption of row planting as sustainable agronomic practices under intercropping and mixed cropping agricultural practices.

Since the adoption of row planting is dichotomous with an option of either adoption or non-adoption, the binomial logistic regression was applied as the most appropriate tool to investigate how each independent variable affects the probability of the occurrence of events [28]. In this regard the probability of farmers practicing row planting is assumed dummy and described as;

$$
y_{i}=\left\{\begin{array}{l}
1=\text { if the } i^{\text {th }} \text { farmer adopt row planting } \\
0=\text { if the } i^{\text {th }} \text { farmer adopt row planting }
\end{array}\right.
$$

Where: $y_{i}$ is the dependent variable (row planting) with probability of adoption or non-adoption.

The distribution of $y_{i}$ is a Bernoulli distribution and can be written as;

$$
Y_{i}=\operatorname{Pr}\left(Y=1\left(y=1 \mid x=x_{i}\right)\right.
$$

The binomial logistic regression model, anticipated to explore the socio-economic, institutional and spatial factors influencing the adoption of row planting is expected to determine the degree and direction of relationship between dependent and independent variables in the adoption of row planting among the households. Hence, row planting, which is projected to be influenced by a set of independent variables is specified as follows: 


$$
\operatorname{Ln}\left[\frac{P_{i}}{1-P_{i}}\right]=\beta_{0}+\beta_{1} x_{1}+\beta_{2} x_{2}+\beta_{3} x_{3}+\ldots \ldots \ldots \ldots . . . . \beta_{k} x_{k i}
$$

Where $\mathrm{P}$ is the probability that a farmer adopts row planting and (1-P) is the probability that a farmer does not adopt row planting the subscript $i$ is the $\mathrm{i}^{\text {th }}$ observation in the sample. $\beta_{0}$ is the intercept term and $\beta_{1}, \beta_{2} \ldots \beta_{k}$ are the coefficients of the independent variables $\mathrm{X}_{1}, \mathrm{X}_{2} \ldots \mathrm{X}_{\mathrm{k}}$

\section{Results and Discussion}

Binomial logistic regression was applied to assess the impact of number factors on the likelihood of adoption of row planting under the inter and mixed cropping systems among the investigated households. However, before the actual computation of logistic regression, the preliminary test of the validity of the model was made. The test was done to check out whether the basic assumptions of binomial logistic regression such as sample size, multicollinearity, and outlier are considered. According to Pallant [29], the small sample size for the dependent variable having a large number of predictors is not recommended for binomial logistic regression analysis.

Multicollinearity test among the predicting variables was performed and fortunately found that no predicting variables was found having a strong correlation $(\mathrm{r} \geq+0.7)$ with other predictors. Therefore, no variable was omitted or formed composite. Besides, collinearity diagnosis was performed to check the validity of tolerance of collinearity statistics and thus no variable having a tolerance value less than 0.1 was found. This is because variables having tolerance values less than 0.1 witnesses the prevalence of a strong correlation among the predicting variables. In addition to this, the prevalence of outliers was checked by the goodness of fit of the model (see Table 1).

Table 1: Logistic regression predicting likelihood of adopting row cropping.

Source: Computed based on survey data, 2018.

\begin{tabular}{|c|c|c|c|c|c|c|c|c|}
\hline \multirow{2}{*}{ Variables } & \multirow{2}{*}{ B } & \multirow{2}{*}{ S.E. } & \multirow{2}{*}{ Wald } & \multirow{2}{*}{ Df } & \multirow{2}{*}{$P$} & \multirow{2}{*}{ Odds Ratio } & \multicolumn{2}{|c|}{$95.0 \%$ C.I. for Odd Ratio } \\
\hline & & & & & & & Lower & Upper \\
\hline $\mathrm{X} 1$ & 0.319 & 0.199 & 2.577 & 1 & 0.108 & 1.376 & 0.932 & 2.032 \\
\hline $\mathrm{X} 2$ & 0.827 & 0.359 & 5.31 & 1 & 0.021 & 2.287 & 1.132 & 4.623 \\
\hline $\mathrm{X} 3$ & 0.284 & 0.338 & 0.709 & 1 & 0.4 & 1.329 & 0.685 & 2.576 \\
\hline $\mathrm{X} 4$ & 0.12 & 0.388 & 0.096 & 1 & 0.757 & 1.128 & 0.527 & 2.413 \\
\hline $\mathrm{X} 5$ & -0.011 & 0.019 & 0.362 & 1 & 0.548 & 0.989 & 0.953 & 1.026 \\
\hline X6 & 0.07 & 0.424 & 0.027 & 1 & 0.869 & 1.072 & 0.467 & 2.461 \\
\hline $\mathrm{X7}$ & 1.965 & 0.552 & 12.676 & 1 & 0 & 7.132 & 2.418 & 21.034 \\
\hline Constant & 1.277 & 1.018 & 1.571 & 1 & 0.21 & 3.584 & & \\
\hline \multicolumn{9}{|c|}{ Goodness-of-fit tests } \\
\hline \multicolumn{9}{|c|}{ Initial -2 Log Likelihood $=277.815$} \\
\hline \multicolumn{9}{|c|}{-2 Log likelihood $=250.454 \mathrm{a}$, Model Chi-square $=4.091$, Classification $=83.2$} \\
\hline
\end{tabular}

The model explained in Table 1 contained seven explanatory variables. Out of the seven predictors, the model contained only two statistically significant variables, $\chi^{2}(7, \mathrm{~N}=303)=27.361$, $\mathrm{p}<0.001$, indicating the model was able to distinguish between the investigated household head who adopted and not adopted row cropping on their farmland. The model as a whole explained between $8.6 \%$ (0.086) (Cox and Snell R square) and $14.4 \%$ or (0.144) (Nagelkerke R square) of the variance in adoption status and correctly classified $83.2 \%$ of cases.

\section{Model presentation}

Based on the result of logistic regression presented in Table 1 , the model representing the relationship between independent variables and the predictors has been drawn. Accordingly, the adoption of row planting under the intercropping and mixed cropping system has been modeled as follows:

$$
\left[\frac{P_{i}}{\left(1-P_{i}\right)}\right]=1.28+0.83 x_{2}+1.95 x_{7}
$$

Farmers' training and frequency of extension contact made a unique statistically significant contribution to the model. The strongest predictor determining adoption was the frequency of extension contact, recording an odds ratio of 7.27. This indicated that farmers who had a usual contact with extension service providers were over 7 times more likely to adopt row cropping than those having no extension contact. Anne M Cafe \& J Sanford Rikoon [17], on their study in South Wollo, revealed that farmers who had extension support adopted row planting of Teff. EGWU \& Emeka [13], revealed a similar result that poorer practice of extension service hampered the adoption of innovations among farmers in Delta State of Nigeria. Studies in arid areas of Tunisia also revealed similar results [14]. On the other hand, farmers' training has also an odds ratio of 2.28. This implies that farmers who took training regarding soil and water conservation were over 2 times more likely to adopt row planting than those having no training. Access to participate in training can let farmers to have a better information regarding field management 


\section{International Journal of Environmental Sciences \& Natural Resources}

[14,16-17]. The situation in Sub-Saharan Africa which goes in line with this finding witness's direct relationship between productivity loss and capacity to innovate which can be enhanced through continuous follow-up and provision of training [30]. Their capacity to innovate in a social, economic, political and cultural context is seen as decisive to reverse the trend of declining soil fertility. Similarly, Stuart R D \& Nieuwoudt WL [15], on their study in South Africa found that farmers who get frequent extension services adopted row cropping technology better as compared to those having no extension contact.

\section{Conclusion}

Row planting as a sustainable agricultural practice in Wolaita Zone was basically introduced by ministry of agriculture and rural development. The practice was however, poorly adopted in the central highlands of Wolaita Zone and it is determined by range of factors. Hence, extension service and farmers off and onsite trainings were the major factors determining the rate of adoption of the technology as sustainable agricultural practices in the highlands.

Hence, the government and office of agriculture together with concerned non-governmental organization should provide off and onsite training on the means and importance of application of the technology. Furthermore, the existing irregular extension service should function properly letting farmers obtain the service whenever they need.

\section{References}

1. UNDP (2018) Implementation of the Third United Nations Decade for the Eradication of Poverty (2018 - 2027). Inter-Agency Group Meeting. Addis Ababa.

2. Bezu S, Holden S (2014) Are Rural Youth in Ethiopia Abandoning Agriculture? World Development 64: 259-272.

3. Nigatu GME, Tsetadirgachew L (2014) Determinants of Arable Land Management Technologies in Damot Gale, Wolaita, Southern Ethiopia. International Journal of Agriculture and Forestry 4(1): 46-52.

4. Challa M (2013) Determining Factors and Impacts of Modern Agricultural Technology Adoption in West Wollega. GRIN Publishing GmbH.

5. World Bank (1973) Ethiopia: Agriculture Sector Review.Washington.

6. Berihun KH, Bihon KA, Kibrom AW (2014) Adoption and Impact of Agricultural Technlogies: Evidences from Southern Tigray. International Journal of Food and Agricultural Economics 2(1): 91-106.

7. Dickey EC, Fenster CR, Laflen JM, Mickelson RH (1983). Effects of Tillage on Soil Erosion in a Wheat-Fallow Rotation. Biological Systems Engineering: Papers and Publications, pp. 1-8.

8. FAO (2012) Small Holders and Family Farmers. FAO, Sustainibility Pathways.

9. Ejegayehu WY (2016) Effect of wheat row planting technology adoption on small farms yield in Ofla Woreda, Ethiopia. International Journal of Agricultural Extension and Rural Development 3(5):184-196.

10. Campion A (2018) Cracking the Nut: Promoting Agricultural Technology Adoption and Resilience. Connexus.

11. Tewodros T, Girmay T, Eyasu E, Mulugeta D, Irene K (2016) Drivers for adoption of agricultural technologies and practices in Ethiopia A study report from 30 woredas in four regions.
12. Pannell DJ, Marshall GR, Barr N, Curtis A, Vanclay F, et al. (2006) Understanding and promoting adoption of conservation practices by rural landholders. Australian Journal of Experimental Agriculture 46: 14071424.

13. EGWU, Emeka W (2015) Factors affecting farmers adoption of innovation in Delta State. Global Journal of Agricultural Economics, Extension and Rural Development 3(2): 177-182.

14. Dhraief MZ, Romdhani SB, Dhehibib B, Oueslati-Zlaouia M, Jebali O, et al. (2018) Factors Affecting the Adoption of Innovative Technologies by Livestock Farmers in Arid Area of Tunisia. FARA Research Report 3(5): 1-22.

15. Stuart RD Ferrer, Nieuwoudt WL (2001) Testing Risk Preferences as Determinants of Farmers: Soil Conservation Decisions in South Africa. Moscow, Russia.

16. Yu B, Nin-Pratt A, Funes J, Asrat S (2010) Cereal Production and Technology in Ethiopia. IFPRI-ESSP II Discussion Paper 12. Washington: international Food Policy Research Institute, p. 35.

17. Anne M Cafer, J Sanford Rikoon (2018) Adoption of new technologies by smallholder farmers: the contributions of extension, research institutes, cooperatives,and access to cash for improving tef production in Ethiopia. Agriculture and Human Values 35(3): 685-699.

18. Melese B (2018) A Review on Factors Affecting Adoption of Agricultural New Technologies in Ethiopia. Journal of Agricultural Science and Food Research 9(3): 1-4.

19. Uaiene R, Arndt C, Masters W (2009) Determinants of Agricultural Technology Adoption in Mozambique.

20. Leah S, Kelly AN, Christopher D (2015) Winter Wheat Row Spacing and Alternative Crop Effects on Relay-Intercrop, Double-Crop, and Wheat Yields. International Journal of Agronomy 2015(369243): 1-8.

21. Singh G, Bhardwaj SP, Singh BP (1979) Effect of row cropping of maize and soybean on erosion losses. Indian Journal of Soil Conservation 7 : 43-46.

22. Mishra Y, Shukla R, Rawat G (2001) Correlation Coefficients and Selection indices in bread wheat (Triticum aesticum aestivum L.) Under different Growing Situation. Indian J Agric Res 35:161-165.

23. Mohammad J, Haider A, Amanullah J (2001) Influence of sowing methods and Mulching on yield and yield Components of Wheat. Pak J Biol Sci 4(6): 657-659.

24. ONCCP/RPOSE (Office of the National Committee for Central Planning/Regional Planning Office for Southern Ethiopia. (1985). A Regional Atlas of Southern Ethiopia. Awassa: RPOSE/Awassa.

25. Creswel JW (2009) Research Design: Qualitative, Quantitative, and Mixed method Approaches (Vol. 3rd edn). India: SAGE Publishing.

26. Heather Powell, Stephanie Mihalas, Anthony J, Christine E Delay, Onwuegbuzie SS (2008) Mixed Methods Research in School Psychology: A Mixed Methods Investigation of Trends in the Literature. Psychology in the Schools 45(4).

27. Israel GD (2012) Determining sample size. University of Florida, USA.

28. Raut N, Bishal K Sitaula, Arild Vatn, Giridhari S Paudel (2011) Determinants of Adoption and Extent of Agricultural Intensification in the Central Mid-hills of Nepal. Journal of Sustainable Development 4(4): 47-60.

29. Jullie Pallant (2007). SPSS Survival Manual. Open University Press, New York, USA

30. Fernando S, Gian N, Christoph S, Adamtey N, Fliessbach A (2018) Testing and adoption of bottom-up agricultural innovations to improve soil fertility in small holder farms in sub Saharan Africa: An interdisciplinary approach. 
Your next submission with Juniper Publishers will reach you the below assets

- Quality Editorial service

- Swift Peer Review

- Reprints availability

- E-prints Service

- Manuscript Podcast for convenient understanding

- Global attainment for your research

- Manuscript accessibility in different formats ( Pdf, E-pub, Full Text, Audio)

- Unceasing customer service

Track the below URL for one-step submission https://juniperpublishers.com/online-submission.php 